\title{
Triads and The Abilities of Transnational Organized Crime to Prevail
}

\author{
Triad dan Kemampuan Kejahatan \\ Transnasional yang Terorganisir untuk \\ Bertahan
}

\author{
Kholifatus Saadah \\ Universitas Jenderal Soedirman
}

\begin{abstract}
Abstrak
Transnational Organized Crime (TOC) adalah bentuk luas dari organisasi kejahatan yang dibentuk oleh sekelompok orang di wilayah tertentu. Dengan adanya globalisasi, perkembangan dari sebuah TOC bisa melewati batas-batas negara dan bahkan balik mengancam entitas dari negara tersebut. Satu hal yang membedakan TOC dengan organisasi kejahatan yang lain adalah struktur dan pola aktivitasnya yang rapi, seperti organisasi transnasional pada umumnya. Salah satu TOC yang melegenda sampai dengan sekarang adalah kelompok mafia dari Cina, Triad. Sebagai organisasi kejahatan yang berumur panjang, berdiri sejak Dinasti Qing pada 1760-an, Triad memiliki banyak cabang yang tersebar di wilayah dengan populasi etnis Cina yang besar selain Cina sendiri seperti Taiwan, Hongkong, Singapura, Amerika Serikat dan Inggris. Melalui tulisan ini, penulis berusaha menjelaskan mengenai perkembangan Triad dari yang awalnya kelompok mafia menjadi kelompok yang memiliki tujuan bisnis seperti korporasi. Langgengnya kekuatan Triad sebagai sebuah organisasi kejahatan disebabkan juga banyaknya celah, baik di institusi domestik maupun institusi internasional. Celah tersebut dimanfaatkan secara baik oleh TOC untuk terus-menerus beraktivitas sampai sekarang.
\end{abstract}

Kata-Kata Kunci: Organisasi Kejahatan Transnasional, TRIAD, Globalisasi, Mafia, Korporasi

Transnational Organized Crime (TOC) is a widespread form of criminal organization formed by a group of people in a particular region. Because of globalization, the development of a TOC can cross the borders of the country and even turn against the entity of the state. One thing that distinguishes TOC from other crime organizations is, its neat structure and pattern of activities, such as transnational organizations in general. One of the legendary TOCs is the mafia group from China, Triad. As a long-lived crime organization, established since the Qing Dynasty in the 1760 s, Triad has many branches scattered in areas with large Chinese ethnic populations other than China itself such as Taiwan, Hong Kong, Singapore, the United States and Britain. Through this paper, I'll try to explain the development of the Triads, from a group that was originally a mafia to a group that has business objectives like a corporation. The lasting power of the Triads as a criminal organization is supported by the gap which happened in domestic and international institution. This gap is used properly by TOC to continue their activities until now.

Keywords: Transnational Organized Crime, TRIAD, Globalization, Mafia, Corporation 
Konstelasi hubungan internasional terkenal memiliki tiga aktor utama, negara, korporasi global dan Organisasi Internasional Nonpemerintah (International Non-Governmental Organizations/ INGO). Ketiga aktor tersebut hadir dan berjalan beriringan sesuai dengan kemampuan dan kapasitas masing-masing. Diantara ketiganya, INGO adalah aktor yang "paling muda" dibandingkan yang lain. Muncul pada abad ke 18, INGO merupakan bentuk aktor yang menyasar isu-isu di luar urusan negara dan korporasi global seperti perbudakan dan air sungai. Tujuan-tujuan dari INGO terkesan mulia, namun ada juga INGO yang tidak memiliki tujuan mulia sama sekali, justru merupakan sumber kejahatan di dunia internasional yaitu Transnational Organized Crime (TOC). Tindakan-tindakan yang dilakukan oleh TOC merupakan tindakan kriminal dan dilakukan oleh oknum-oknum tertentu di suatu negara. Namun yang menjadi perhatian terkait TOC adalah bentuknya yang terorganisir serta range transnasional yang dimiliki. TOC pada awalnya merupakan masalah domestik, sebuah tindakan kejahatan yang dilakukan baik kelompok maupun individu. Globalisasi merupakan aspek yang mendukung internasionalisasi TOC, sehingga mampu menjadi masalah transnasional.

Dalam tulisan ini akan dibahas mengenai bagaimana Triad, mafia dari China yang awalnya merupakan organisasi yang dibentuk dengan tujuan menggulingkan Dinasti Qing, berkembang menjadi salah satu organisasi bisnis bawah tanah dan bertanggung jawab atas beberapa tindakan kriminalyang terjadi di Cina dan sekitarnya. Selain itu, lingkup kerja dari Triad ini melibatkan wilayah maupun negara yang memiliki banyak etnis Cina, tentu hal ini akan menjadi pembahasan yang menarik mengingat sebagai organisasi kriminal Triad tentu memiliki modus operasi bawah tanah yang cukup kuat sehingga mampu menjalankan organisasinya secara transnasional. Ditambah lagi, sebagai organisasi yang bergerak di akar rumput, Triad memiliki kemudahan untuk memiliki akses kepada masyarakat secara langsung. Hal inilah yang kemudian bisa membentuk kekuatan kriminal yang tidak terdeteksi secara cepat oleh negara maupun organisasi internasional. Dalam tulisan ini akan dibahas mengenai perkembangan organisasi kejahatan yang merupakan aktor baru di dalam hubungan internasional, serta peranan globalisasi di dalamnya. 


\section{Organisasi Kejahatan Transnasional: Aktor Baru yang Semakin Berkembang}

Milston \& Johnson (1999, 103) mengungkapkan bahwa dalam satu dekade terakhir, terutama sejak Perang Dingin berakhir, TOC berkembang menjadi fenomena yang tidak dapat dihentikan, merasuk cukup dalam pada masyarakat sipil. Salah satu scholar yang membahas mengenai organisasi kejahatan dan globalisasi sebagai pengaruhnya adalah Karl Polanyi. Dalam tulisannya, Polanyi mengungkapkan bahwa adanya TOC merupakan respon dari pasar bebas ketika korporasi global dan negara saling bersaing untuk mendapatkan keuntungan (Milston \& Johnson 1999, 105). Lebih lanjut, interaksi antara kedua aktor yang sibuk "bersaing" di dalam dinamika pasar internasional dengan organisasi kejahatan muncul pada masa setelah perang, dimana pada masa-masa tersebut ada banyak hal yang tidak legal untuk dilakukan jual beli.

Namun, definisi dari organisasi kejahatan, terutama dalam hal transnasional, belum memiliki kesepakatan yang jelas di dalam perkembangannya. Apakah hanya sekedar kejahatan yang terorganisir dengan baik? Sebuah tindakan kejahatan yang mampu meloloskan diri dari jeratan hukum pemerintah yang sah? Atau bahkan sebuah jaringan bawah tanah yang menguasai komoditaskomoditas tertentu di dalam perdagangan internasional? Jawaban atas pertanyaan-pertanyaan tersebut seakan masih menggantung, mengingat definisi dari TOC sendiri masih berada dalam perdebatan (Pankratz \& Matiasek 2012, 41). Bahkan, untuk menyebut TOC sebagai ancaman terhadap keamanan nasional suatu negara masih dipertanyakan (Campbell 2014, 1). Tetapi, menurut Campbell juga, perkembangan TOC sendiri sudah mulai mendekati konteks politik negara maupun kawasan, bahkan internasional. Untuk itulah, perlu adanya perhatian khusus dalam melihat perkembangan dari aktor yang muda ini. TOC dapat dikatakan baru mengambil perhatian dunia internasional setelah Perang Dingin berakhir. Hal ini dapat dijelaskan melalui konteks bahwa pada saat Perang Dingin berlangsung, masalah-masalah keamanan hanya terpusat pada persaingan senjata antar kedua negara besar, Amerika Serikat dan Uni Soviet. Baru ketika Uni Soviet runtuh dan Perang Dingin dinyatakan berakhir, masalahmasalah seperti organisasi kejahatan muncul ke permukaan 
bersamaan dengan masalah-masalah keamanan lain seperti terorisme dan perubahan iklim (Pankratz \& Matiasek 2012, 42). Apabila membicarakan mengenai TOC sebagai aktor baru, aspek kebaruannya ada pada transnasional. Hal ini berkaitan dengan munculnya organisasi kejahatan dari masa lampau, TRIAD yang menjadi studi kasus pada tulisan kali ini bahkan sudah ada sejak abad ke-17 pada Dinasti Qing. TOC mampu bergerak apabila ada dukungan dalam hal transportasi dan distribusi, disinilah kemudian globalisasi memegang peranan penting (Milston \& Johnson 1999, 106). Organisasi kejahatan pada awalnya memang isu keamanan internal, dimana ada sekelompok preman atau penjahat yang menimbulkan kekacauan, terkadang dibarengi dengan aktivitas narkoba, geng motor, bahkan korupsi di tubuh pemerintahan. TOC merupakan bentuk advance, ketika organisasi kejahatan terkait dengan jaringan yang berada melewati batas negara.

TOC bukan lagi seharusnya dilihat sebagai sesuatu yang tidak normal, justru TOC adalah hal normal karena merupakan bentuk reaksi dari fenomena yang terjadi di masyarakat. TOC bahkan mampu menyentuh semua aspek di dalam masyarakat, mengingat jangkauannya yang meluas (Pankratz \& Matiasek 2012, 42). Lebih lanjut, tujuan utama dari TOC yang sangat dekat dengan masyarakat, yaitu keuntungan, menjadikan lingkup penyebaran pengaruhnya mampu mengenai hampir semua elemen di dalam kehidupan masyarakat sipil. Bahkan, TOC bisa disamakan dengan kinerja dari firma global dimana kinerjanya bisa menyentuh baik diatas negara maupun dibawah negara. Diatas negara memiliki arti bahwa TOC bisa bergerak leluasa antar negara, melewati batas negara satu dengan yang lain dan bahkan mampu membentuk sistem antar negara bagi mereka sendiri (Milston \& Johnson 1999, 109).

Nilai lebih dari TOC di dalam menjalankan aktivitasnya beyond state, adalah keleluasaan yang dimiliki karena tidak ada negara yang memiliki wewenang penuh untuk membatasi aktivitas mereka, pembatasan aktivitas mereka hanya terbatas pada bagaimana kemudian TOC tidak memberikan ancaman bagi suatu negara. TOC bisa membangun sistem perdagangan dan pekerjanya sendiri, inilah yang kemudian membedakan TOC 
dengan sistem lain dimana mereka cenderung bebas namun tetap terorganisir. Beberapa fakta membuktikan, seperti Golden Crescent di Afganistan dan Golden Triangle di Myanmar, pihak yang melakukan jual beli serta distribusi opium dari kedua tempat tersebut ke seluruh dunia adalah penjahat yang terorganisir sehingga bisa terus melakukan aktivitas haramnya sampai dengan sekarang. Sedangkan dibawah negara, adalah aktivitas-aktivitas TOC yang menyasar kaum pinggiran atau kaum marjinal. Aktivitas ini terkait dengan sumber daya dan harga yang harus dibayar ketika menyesuaikan dengan globalisasi yang sedang berjalan dan menjadi salah satu kekuatan TOC (Milston \& Johnson 1999, 109). Permasalahan sumber daya, terutama manusia, memang lebih mudah apabila mengincar mereka yang tidak terdidik dan miskin. Dengan diiming-imingi keuntungan yang besar, maka akan mudah bagi antek-antek TOC untuk merekrut mereka untuk menjadi bagian dari kejahatan transnasional.

Globalisasi secara langsung mendorong perkembangan TOC menjadi semakin meluas (William 2001). Ada setidaknya tujuh aspekyang mendorong semakin berkembangnya TOC, dan kondisikondisi tersebut banyak dipengaruhi oleh globalisasi. Pertama, dengan adanya globalisasi maka kemudahan perdagangan dan teknologi menjadi semakin mudah. Kemudahan inilah yang kemudian menjadi katalis bagi perkembangan TOC. Walaupun dengan bentuk yang lama, seperti Mafia Sisilia dan Triad di Cina, adanya teknologi akan sangat membantu penyebaran barang dagangan dari para penjahat tersebut.

Kedua, globalisasi juga mendorong jumlah migrasi besar-besaran dan memberikan keuntungan bagi TOC. Keuntungan ini dapat berbentuk sebagai adanya sumber daya manusia untuk direkrut dan menjadi perekrut (William 2001). Terkadang, perpindahan yang terjadi karena faktor ketidakamanan dari wilayah asal. Para migran akan cenderung merasa bingung dan penuh kekhawatiran setelah melakukan migrasi, untuk itulah anggota TOC bisa memanfaatkan kondisi mereka sebagai ladang sumber daya. Para migran cenderung membutuhkan pekerjaan dan penghasilan, terkadang tidak memerhatikan latar belakang dari pihak yang menawarkan pekerjaan tersebut. Demikian adalah salah satu strategi dari TOC untuk melakukan perekrutan anggota baru 
mereka.

Ketiga adalah keuntungan yang sangat besar. Proses "berjalannya" uang yang ilegal menjadi salah satu aspek yang membuat hukum legal mengalami kesulitan dalam melacaknya (William 2001). Kondisi ini kemudian didukung dengan semakin menariknya pasar dari barang-barang ilegal yang mendasari TOC tersebut. Barangbarang yang diedarkan cenderung limited dan hanya pihak-pihak tertentu yang dapat mengaksesnya. Karena itulah harga yang dipatok terkadang sangat mahal, disitulah letak keuntungan yang diperoleh oleh TOC. Dengan semakin besarnya keuntungan yang diperoleh dari kegiatan haram, maka akan semakin besar TOC tersebut mampu melakukan ekspansi karena didukung oleh SDM yang cukup banyak serta permintaan pasar yang sangat besar. Seperti yang sudah diungkapkan sebelumnya bahwa tujuan utama TOC adalah profit, maka dengan adanya profit yang sangat besar, semakin besar pula minat orang-orang untuk terlibat ke dalam TOC dengan segala risiko yang ada. Hal ini ditambah dengan mekanisme kerja TOC yang cenderung berada "bebas" dari aturan yang mengikat aktivitas mereka.

Keempat, semakin menariknya keuntungan dari aktivitas-aktivitas yang dilakukan oleh TOC seiring waktu berjalan (William 2001). Dapat dicontohkan pada tahun 1980-an, ketika perdagangan narkoba dan obat-obatan terlarang lainnya mengalami peningkatan, dimana tidak lagi hanya Amerika Serikat yang mengalami kebingungan untuk mengatasi masalah ini namun juga wilayah lain. Selain narkoba, praktik jual beli juga mengalami peningkatan dari tahun ke tahun mengingat banyaknya kasus kehilangan orang di negara-negara miskin dan berkembang. Bisnis tersebut menarik, dan cenderung atraktif mengingat jumlah keuntungan yang bisa didapatkan.

Kelima, perbedaan keuntungan. Perbedaan keuntungan yang dimaksudkan adalah perbedaan antara perdagangan legal dan ilegal (William 2001). Ambil contoh rokok. Melalui pasar normal, harga rokok di beberapa negara maju sangatlah tinggi, mengingat banyak negara yang mulai menerapkan kebijakan untuk mengurangi peredaran rokok. Dibandingkan dengan harga rokok yang dijual melalui jalur bawah tanah, harga yang tidak melewati bea cukai akan cenderung lebih murah. Tentu saja konsumen 
akan mencari rokok-rokok tersebut dan bahkan para pemasok akan menggunakan kesempatan ini untuk menjalankan bisnisnya. Hal inilah yang kemudian mendorong semakin banyaknya penyelundupan rokok dari satu negara ke negara lain.

Keenam, adanya perbedaan antara satu negara dan negara lain di dalam menerapkan hukum dan aturan terkait dengan TOC memunculkan adanya celah diantaranya. Kondisi ini bisa saja terjadi di sektor keuangan dan perbankan, terkadang keamanan keduanya berbeda antara satu negara dengan yang lain. Misalnya dibandingkan mengenai aturan untuk membuka dan mengirim uang melalui bank di Swiss dengan di Indonesia. Swiss akan cenderung lebih sulit sehingga praktik money laundering menjadi sedikit. Berbeda dengan Indonesia yang tidak memiliki batasan jelas ketika melakukan transaksi ke luar negeri sehingga banyak dana-dana fiktif yang ternyata miliki TOC beredar luas.

Ketujuh adalah perbedaan kapabilitas dan hukum di setiap negara dalam menghadapi TOC (William 2001). Hal inilah yang membuat TOC semakin banyak di kawasan-kawasan negara yang masih berkembang atau bahkan miskin, karena ketidakmampuan mereka untuk menangani TOC itu sendiri. Hal ini berkaitan juga dengan risiko yang harus diambil oleh negara untuk melakukan intervensi kepada TOC. Ketika TOC dihadapkan pada negara berkembang, mereka justru mampu memanfaatkan banyak celah pada negara tersebut, terutama apabila negara tersebut sedang mengalami krisis. Dapat dipastikan bahwa negara tersebut tidak akan melihat TOC sebagai masalah yang diprioritaskan.

Salah satu hal menarik dari TOC adalah pattern yang dijalankan. Beberapa TOC sejatinya merupakan organisasi kejahatan yang sudah ada sejak lama, Triad sudah ada pada abad ke-17 begitu juga dengan Bajak Laut di Selat Malaka. Kedua organisasi kejahatan ini sudah beroperasi sejak lama di wilayah masing-masing, namun seiring waktu berjalan mereka melebarkan "sayapnya" ke berbagai sektor dengan bantuan globalisasi itu sendiri. Tujuan awal TOC adalah jelas, yaitu menghasilkan uang sebanyak-banyaknya. TOC sendiri adalah bentuk lanjutan dari organisasi kejahatan pada umumnya, dengan beberapa tambahan seiring waktu berjalan. Milston \& Johnson 1999, 111) mengungkapkan bahwa: 


\begin{abstract}
"Insofar as the purpose of organized crime is to make money, these groups are typically regarded as predominantly economic actors. Their profit comes not merely from theft, but today from emulating market mechanisms? Forming strategic alliances, investing (and laundering) their capital, plowing it into new growth areas (e.g., dumping toxic wastes that abuse the environment in developing countries and then negotiating lucrative contracts for the cleanup industry), directing a share of their returns into $\mathrm{R} \& \mathrm{D}$, adopting modern accounting systems, utilizing global information networks that have no frontiers, and insuring (protecting) themselves against risks or threats to their organizations. Whereas these groups may have ostensibly economic objectives, to the extent that they undermine the main actors in the globalization process? Trans border firms and dominant states that acquiesce to it? Then transnational organized crime groups are both a political component of and a response to globalization."
\end{abstract}

Kutipan di atas menjelaskan bahwa TOC sudah mengalami banyak pergeseran. Penghasilan yang didapatkan tidak lagi murni dari "pencurian" yang mereka lakukan. Dengan bantuan globalisasi, mereka mampu membentuk jaringan dan aliansi untuk memperbesar pemasukan. Selain itu, kemudahan teknologi yang mereka pelajari juga bisa membantu dalam hal penghitungan maupun investasi agar uang yang dimiliki tidak hanya berada di dalam satu tempat saja. Memutar uang di berbagai tempat bisa menjadi salah satu strategi agar uang-uang tersebut tidak terendus pihak yang berwajib. Lebih lanjut, TOC juga akan memanfaatkan posisi mereka di kancah politik untuk melanggengkan entitasnya, begitu juga dengan sebaliknya. Entitas para pelaku politik yang menyeleweng juga bisa dijaga oleh TOC, mengingat pengaruh mereka yang cukup besar. Sejalan dengan pemikiran William (2001), yang mengungkapkan bahwa sejatinya TOC adalah bentuk kejahatan lama dengan model baru, memanfaatkan globalisasi dan kemudahan-kemudahan yang ada.

\title{
Triad dan Perkembangannya
}

Salah satu organisasi kejahatan di dunia yang berumur cukup panjang adalah mafia dari Cina, yaitu Triad. Beberapa fakta 


\section{Kholifatus Saadah}

membuktikan bahwa para mafia Cina ini melakukan banyak tindakan kriminal yang mencapai Amerika Serikat. Pada tahun 1993 misalnya, petugas Bea Cukai di pelabuhan New York berhasil menggagalkan penyelundupan hampir 300 orang beretnis Cina (Bolz 1995, 147). Orang-orang tersebut ternyata sakit dan hampir tidak memiliki harapan, pandangan mereka kosong dan satusatunya keinginan mereka adalah mendapatkan pekerjaan yang layak di Amerika Serikat. Setelah diusut, penyelundupan 300 orang melalui perahu kargo ini ternyata merupakan salah satu aktivitas dari Triad.

Triad sendiri merupakan organisasi rahasia di Cina, yang terkenal memiliki 3 simbol. Ketiga simbol tersebut mewakili surga, dunia dan manusia, gambaran mengenai sebuah organisasi yang semireligius di dalam segala aktivitasnya (Bolz 1995, 148). Triad sendiri terbentuk sebagai bentuk resistansi Dinasti Qing, berlandaskan nasionalisme karena menganggap apa yang sudah dilakukan oleh dinasti tersebut adalah bentuk penodaan terhadap etnis asli Cina, dimana mereka melibatkan pihak asing di dalam pemerintahan Dinasti Qing. Pada awal pembentukannya, Triad adalah sebuah organisasi yang berisikan orang-orang berpendidikan tinggi, maka dari itu mereka mampu menarik perhatian dari masyarakat Cina sendiri (Overholt 1995, 42). Seiring waktu berjalan, Triad mampu menjadi salah satu bagian dari masyarakat Cina sendiri. Bahkan, beberapa pengusaha dan kelompok tertentu secara sukarela membayar "uang keamanan" kepada Triad secara rutin. Kondisi ini tentu saja menggambarkan bahwa sebenarnya Triad, sebagai sebuah organisasi merupakan salah satu bagian dari masyarakat sipil di Cina pada masa itu.

Ketika Dinasti Qing berakhir pada 1911, Triad tidak kemudian bubar karena sudah mencapai tujuannya. Justru Triad semakin mengembangkan kapasitasnya sebagai organisasi, yang awalnya adalah organisasi nasionalis menjadi organisasi yang berbasis kejahatan (Bolz 1995, 148). Seiring waktu berjalan, Triad kemudian menjadikan dirinya sebagai organisasi kejahatan, sebagai bentuk respon dari pemerintah Cina yang dianggap tidak mampu menjalankan fungsinya dengan benar. Salah satu kekuatan besar Triad yang membuatnya mampu bertahan dan berkembang adalah posisinya di tengah-tengah masyarakat Cina. Tidak hanya sekedar 
organisasi, Triad adalah bagian dari masyarakat Cina sendiri. Keanggotaan Triad juga tidak sedikit, bahkan beberapa sumber menyebutkan bahwa ada setidaknya 7 sub-organisasi Triad yang tersebar di seluruh dunia, terutama di negara-negara dengan populasi penduduk Cina yang besar. Tidak semua sub-organisasi tersebut semurni Triad, seperti yang awal dibentuk, namun jaringan yang dimiliki menandakan bahwa kekuatan Triad sudah berkembang dari yang awalnya hanya sebatas organisasi di dalam suatu negara menjadi organisasi yang berbasis transnasional.

Salah satu "cabang" Triad yang cukup besar, selain di Cina sendiri adalah Hongkong. Tercatat, ada setidaknya tiga "cabang" Triad di wilayah bekas koloni Inggris tersebut, the $14 \mathrm{~K}$, Sun Yee On group dan the Wo group (Overholt 1995, 42). Beberapa geng-geng preman dan motor di jalanan Hongkong, yang bertanggung jawab atas beberapa kejahatan di jalanan Hongkong disinyalir dilindungi oleh Triad dan cabangnya (Lo 2010, 851). Hal ini dapat dijelaskan bahwa di dalam organisasinya, para anggota Triad adalah saudara. Sehingga dimanapun mereka berada, maka setiap anggota yang memiliki kekuatan lebih wajib memberikan perlindungan kepada mereka yang membutuhkan. Kondisi inilah yang kemudian memberikan "kelanggengan" bagi geng-geng kejahatan dengan level kecil tetap bertahan. Selain "melindungi" geng-geng kecil tersebut. Triad terutama di Hongkong, juga berada di dalam konstelasi korporasi global. Walaupun ada struktur dan hierarki yang jelas, anggota Triad yang bergabung maupun membentuk korporasi global di Hongkong tanpa harus meminta izin dari organisasi tersebut (Lo 2010, 852). Hal ini juga menandakan bahwa Triad tidak hanya "murni" melakukan kejahatan namun juga melakukan aktivitas-aktivitas normal seperti masyarakat Cina pada umumnya, walaupun banyak sumber mengungkapkan anggota-anggota Triad merupakan pihak yang bertanggung jawab atas kejahatan transnasional yang terjadi dari Cina dan sekitarnya.

Kegiatan Triad yang menjadi sorotan dunia internasional adalah trafficking dan smuggling. Objek yang diperdagangkan cukup banyak, dari manusia sampai dengan heroin dengan lingkup penjualan mencapai Amerika Serikat dan Eropa. Kondisi Cina yang "tidak aman" mendorong sekelompok orang ingin keluar dari salah satu negara dengan penduduk terbanyak di dunia tersebut 
untuk mendapatkan pekerjaan dan kehidupan yang layak. Triad menggunakan kesempatan ini untuk "memberikan fasilitas" kepada mereka yang membutuhkan, menawarkan jalan untuk pergi dari Cina ke tempat yang lebih baik (Bolz 1995, 149). Selain itu, sebagai negara dengan penduduk yang sangat banyak, nomor 1 di dunia, Cina tergolong tidak memiliki lapangan pekerjaan yang banyak sehingga menyebabkan kondisi perekonomian domestik Cina buruk, Hal inilah yang kemudian mendorong banyaknya trafficking, yang dikelola oleh Triad karena banyak memberikan keuntungan bagi Triad sendiri (Weiss 2014). There's no free lunch apabila merujuk pada pepatah populer, begitu juga dengan modus operasi dari Triad di dalam mengirimkan sejumlah manusia ke negara lain. Banyak diantara mereka adalah orang-orang yang terlibat hutang dengan Triad, sehingga harus mencari pekerjaan yang layak untuk membayar hutang-hutang tersebut. Terkadang, para pengutang dikirim ke tempat-tempat yang tidak layak untuk bekerja seperti di pabrik-pabrik maupun kawasan terpencil dimana mereka sendiri pun tidak tahu letaknya di peta. Praktik ini berjalan cukup lancar, ada setidaknya dua penyebabnya. Pertama, jaringan kejahatan ini tersebar secara sempurna hampir di seluruh Asia. Kondisi ini mempersulit polisi setempat untuk melakukan investigasi karena apa yang ingin dibuktikan tersebar luas dan sangat rapi, mengingat rata-rata anggota Triad sendiri adalah mereka yang terdidik dari awal. Kedua, rata-rata yang menjadi korban dari Triad ini adalah mereka yang memiliki hutang dengan Triad sendiri. Hal tersebut mendorong mereka untuk bungkam dan terus melakukan apa yang diperintahkan oleh Triad guna membayar hutang mereka (Overholt 1995, 43).

Heroin dan obat-obatan terlarang juga menjadi salah satu aktivitas transnasional Triad. Mengingat bahwa Myanmar dengan Golden Triangle-nya merupakan salah satu penghasil heroin terbesar di dunia, Triad menjadi salah satu agen yang berperan aktif di dalam penyebaran heroin tersebut ke seluruh penjuru dunia (Overholt 1995, 43). Sumber pemasukan terbesar Triad juga disinyalir berasal dari proses penjualan heroin dan beberapa obat terlarang lainnya, mengingat harga di pasar gelap pasti akan sangat mahal karena barang tersebut tidak dijual bebas di pasar internasional pada umumnya. Kelebihan mereka di dalam penjualan heroin ini adalah pendapat dunia internasional bahwa perdagangan obat- 
obatan haram masih dikuasai oleh Mafia Sisilia, mengabaikan bahwa Triad justru lebih dekat dengan sumber daya heroin itu sendiri. Posisi Myanmar, terutama wilayah yang menjadi ladang heroin, cukup dekat dengan Sungai Mekong. Hal inilah yang kemudian mempermudah Triad dari Cina untuk melakukan aktivitasnya di sekitaran sungai terkait dengan heroin ini (Chouvy 2013, 12). Wilayah tersebut sejatinya cukup terisolir, namun justru itulah kelebihannya. Dengan menggunakan transportasi sungai, Triad dan beberapa petani heroin bisa lolos dari pengawasan polisi gabungan antara Thailand, Myanmar dan Laos. Penggunaan kemudahan transportasi setelah mencapai Cina juga memberikan banyak kontribusi bagi Triad untuk memasarkan heroin sampai dengan Amerika bagian Utara dan Eropa.

Tidak hanya dalam bidang ekonomi, Triad juga memiliki aktivitas haram yang berkaitan dengan politik dan ekonomi Cina. Salah satunya adalah kasus yang melibatkan pemimpin Sun Yee On dengan Hongkong Stock Exchange-listed Company (China Prosperity Holding) dalam memanipulasi harga saham di dalam proses pembelian saham pada awal 1999 sampai dengan Oktober 1999 (Lo 2010, 860). Pemimpin Sun Yee On dan juga pemilik Win's Prosperity Group, Jimmy Heung dituduh memanipulasi harga saham CPH agar Jimmy bisa membeli dengan harga sangat murah dibandingkan dengan harga yang ditawarkan pada yang lain. Masalah semakin rumit ketika aktivitas Jimmy, walaupun pada akhirnya tidak bisa dibuktikan di pengadilan, bocor ke media massa. Hal ini menimbulkan banyak protes terutama mengingat bahwa Jimmy adalah salah satu petinggi Triad di Hongkong.

Aktivitas-aktivitas Triad tersebut sejatinya baru muncul dan berkembang setelah Dinasti Qing runtuh, ketika Triad mengalami pergeseran dari organisasi berbasis nasionalisme menjadi organisasi kejahatan yang memanfaatkan aspek globalisasi untuk melancarkan aktivitasnya. Human and drugs trafficking tidak akan berjalan lancar apabila Triad tidak menggunakan kemudahan transportasi dan komunikasi untuk mengirimkan manusia dan barang melalui beberapa moda transportasi. Apabila Triad masih menggunakan model tradisional, dapat dipastikan bahwa mereka akan dengan mudah diciduk oleh pihak berwajib. Selain itu, dengan perbedaan keuntungan yang sangat besar maka 
banyak pihak yang terus-menerus tertarik terhadap TOC ini. Harga saham misalnya, akan sangat menguntungkan, walaupun sejatinya melanggar, apabila membeli saham dengan harga jauh lebih murah dan bisa mendapatkan saham tinggi. Dengan tetap adanya hal-hal seperti ini, maka dapat dipastikan bahwa Triad dan TOC yang lain akan tetap ada dan berkembang sesuai dengan perkembangan jaman.

\section{Pola Kerja Triad: Kelompok Masyarakat Sipil atau Korporasi?}

Secara tradisional, korporasi memiliki tujuan untuk mendapatkan keuntungan dan juga memberikan keuntungan bagi yang terlibat di dalamnya. Keuntungan itu bisa berupa bantuan dari investor, kompensasi untuk karyawan, dan manfaat untuk pelanggan (Post dkk. 2002, 8). Tujuan untuk mendapatkan keuntungan inilah yang kemudian menjadi daya tarik korporasi dibandingkan dengan aktor lain; karena kekuatan keuangan dari sebuah korporasi bisa saja menyaingi negara. Bentuk korporasi bisa saja berbentuk nasional, transnasional maupun global, tergantung pada cakupan aktivitas yang dijalankan. Secara definisi, korporasi memiliki landasan hukum yang mendasari berdirinya korporasi dan aktivitas yang dilakukannya.

Sedangkan Triad dan beberapa organisasi masyarakat rahasia yang ada di dataran Cina, memiliki banyak modus operandi yang bisa membuat mereka melebur dengan kuat di masyarakat (Chen 2005, 79). Praktiknya, walaupun masa sudah bergeser ke arah yang lebih modern, justru Triad berhasil memanfaatkan kondisi tersebut dengan tepat. Globalisasi pada dasarnya juga memberikan "bantuan" bagi Triad. Adanya mekanisme pasar yang semakin maju, memberikan kondisi yang tidak seimbang bagi kawasan-kawasan yang tertinggal. Di Cina, kawasan yang tertatihtatih dalam mengikuti perkembangan pasar global, Triad masuk melalui celah-celah tersebut dengan menyediakan barang secara ilegal yang membuat harga dari barang tersebut bisa lebih murah dari harga barang secara legal. Selain itu, perkembangan pasar yang cepat, terutama di negara Cina yang memiliki banyak pelaku industri, juga melibatkan Triad sebagai salah satu "penyokong" 
dari berjalannya industri tersebut. Industri yang memiliki aktivitas ilegal bukan hal baru di Cina, dan untuk mempertahankan hal tersebut, para pelaku industri harus memutar otak agar tidak terkena imbasnya. Biasanya, mereka akan menyewa Triad yang memiliki koneksi juga di kalangan pasar ilegal, agar bisa mempertahankan industrinya (Wang \& Antonopoulos 2016, 293).

Namun, selain masuk ke dalam industri yang berjalan sebagai "penjaga", Triad juga memiliki mekanisme sendiri dalam menjalankan bisnisnya. Menurut Lo \& Kwok (2012, 83), dalam perkembangannya, Triad mengalami apa yang disebut mainlandization, terutama Triad yang berada di Hongkong. Mainlandization merupakan sebuah proses yang memberikan penjelasan bahwa Triad yang berada di Hongkong akan semakin tergantung dengan Triad yang berada di Cina daratan. Ketergantungan ini berimbas positif bagi Triad di Hongkong sendiri, aktivitas yang dilakukan akan cenderung transnasional dengan mengandalkan koneksi dan kekuatan Triad di Cina daratan yang jauh lebih kuat dibandingkan Triad di Hongkong ataupun di negara lain. Gambetta (1993 dalam Chu 2000, 125126) mengungkapkan bahwa posisi Triad sebagai mafia tidak serta-merta disebut sebagai pelaku usaha. Argumen ini dibangun melalui temuan bahwa Triad tidak menyediakan secara langsung barang-barang ilegal yang mereka jual belikan, namun lebih ke menyediakan jasa untuk penjualannya. Seperti yang dijelaskan pada subbab sebelumnya, Triad banyak terlibat dalam proses penjualan heroin dari Golden Triangle di Asia Tenggara. Triad tidak terlibat sebagai penjualnya, namun mereka adalah pihak yang mengatur proses penjualan barang-barang tersebut sampai bisa diekspor ke banyak tempat di dunia. Di Hongkong misalnya, kondisinya bukan dari Triad menginisiasi sebuah bisnis, namun pelaku bisnis atau misalnya teknisi kasino yang memutuskan untuk bergabung ke Triad dengan tujuan mencari perlindungan (Chu 2000, 127). Berawal dari kondisi-kondisi yang demikian, Triad bisa menjalin koneksi dan mendapatkan banyak informasi terkait aktivitas perdagangan ilegal, baik di dataran Cina maupun melibatkan cabang Triad di seluruh penjuru dunia. Walaupun demikian, penulis berpendapat bahwa apa yang dijalankan Triad bisa tergolong aktivitas bisnis yang menghasilkan keuntungan, ditambah dengan jaringan yang luas, praktis membuat Triad bisa 
menjadi bentuk entrepreneurship yang cukup menjanjikan.

Argumen mengenai aktivitas Triad sebagai salah satu aktivitas bisnis dapat dilihat dari peranan konsep mainlandization yang membuat hubungan antara Triad Hongkong dengan dataran Cina semakin kuat. Pihak Triad di dataran Cina memberikan banyak pengetahuan mengenai teknologi dan juga koneksi yang kuat dengan pelaku bisnisnya lain, dan sebagai timbal baliknya, Triad di Hongkong memberikan banyak pekerja dengan bayaran murah, sex labors, dan beberapa obat-obatan ilegal (Lo \& Kwok 2012, 84). Triad menjalankan operasi kejahatannya seperti menjalankan sebuah korporasi yang memiliki koneksi secara transnasional. Mereka mampu memberikan servis yang tidak diberikan oleh institusi legal; karena memang yang dibutuhkan adalah servis yang ilegal. Beberapa aktivitas Triad, baik secara organisasi dan individu terbukti mempertimbangkan keuntungan, target pasar yang tepat dan strategi untuk mengatur keuangan. Berbeda dengan mafia Sisilia yang terbukti banyak mengalami kebangkrutan ketika menjalankan bisnis, baik secara kelompok dan individu (Chu 2000, 128), logika bisnis berjalan di Triad, bahkan bisa dikatakan mulai mengabaikan "pengkultusan" organisasi; logikanya jika pelaku bisnis yang merupakan anggota Triad meninggal, harta dan legacy-nya tidak akan lari ke organisasi secara penuh. Anggota Triad bisa secara bebas menjalin hubungan maupun memulai bisnis dengan siapapun tanpa harus menunggu saran dari petinggi Triad; namun mereka bisa menggunakan koneksi yang dimiliki Triad untuk menjalankan bisnisnya.

Pemahaman mengenai logika bisnis dan korporasi dapat berkembang pesat di kalangan anggota Triad disebabkan karena black economy di dataran Cina masih sangat kental, ditambah dengan guanxi ${ }^{1}$ yang masih mengakar kuat di dunia bisnis di Cina. Triad's brotherhood tidak lagi menjadi nilai yang dijunjung tinggi oleh anggota Triad pada masa modern ini. Justru, logika yang dibangun adalah logika korporasi yang menekankan keuntungan bagi mereka yang terlibat di dalam lingkaran bisnis tersebut. Adanya pemahaman tersebut mendorong anggota Triad yang original, mereka yang masuk ke dalam Triad karena

1 Guanxi merupakan istilah dalam budaya Cina yang memiliki arti pemanfaatan power dari koneksi yang dimiliki. Konsep tersebut merupakan konsep yang wajar dilakukan oleh pelaku bisnis dari Cina 
sudah memiliki bisnis sendiri dan mereka yang memiliki bisnis serta membutuhkan servis dari Triad, saling bekerja sama untuk mendapatkan keuntungan bagi mereka sendiri (Lo \& Kwok 2012, 84). Aktivitas bisnis mereka mencakup banyak wilayah, terutama seperti yang dijelaskan sebelumnya, Triad memiliki banyak anggota yang tersebar di seluruh penjuru dunia dan bisa digunakan sebagai salah satu poin memperlebar jangkauan bisnis tersebut.

\section{Triad dan Celah Institusi terhadap Transnational Organized Crime}

Munculnya TOC dalam sebuah negara, biasanya ditandai dengan adanya celah untuk berbuat kejahatan itu sendiri. Triad misalnya, berhasil memanfaatkan lubang yang berada di perbatasan untuk melakukan penyelundupan baik barang haram maupun manusia. Adanya kejahatan yang terjadi secara terus-menerus seharusnya menjadi sebuah peringatan baik untuk negara maupun institusi supra-nasional untuk lebih peduli terhadap kemungkinan adanya perkembangan lebih lanjut mengenai kejahatan transnasional dan terencana. Institusi internasional maupun supra-nasional sejatinya sudah memiliki beberapa konvensi maupun badan yang bertugas untuk menangani masalah-masalah kejahatan transnasional ini. ${ }^{2}$ Upaya-upaya tersebut antara lain seperti Konvensi PBB terkait dengan pelarangan peredaran narkotika dan psikotropika tanpa izin melalui UN Drug Convention dan Konvensi Tindak Pidana Pencucian Uang oleh The Council of Europe's Convention on Laundering, Search Seizure and Confiscation of the Proceeds from Crime (Haryanto 2020).

PBB melalui the United Nations Office on Drugs and Crime (UNODC) membentuk the Conference of Parties (COP) yang memiliki fungsi untuk menjalankan aturan-aturan yang dibentuk oleh United Nations Convention against Transnational Organized Crimes. Namun, dapat dilihat bahwa melalui COP, ada beberapa celah dan kekurangan yang mengakibatkan tidak diterapkannya mekanisme pencegahan TOC ini sendiri. Celah dan kekurangan

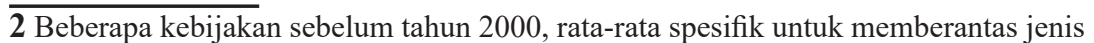
kejahatan transnasionalnya, bukan organisasi yang berada di belakang kejahatan tersebut 
tersebut bisa dilihat pada tidak adanya mekanisme yang memaksa negara untuk merasa terancam dari kegiatan TOC, karena memang belum ada norma dan prinsip yang disepakati bersama (Obokata 2010, 208). Dalam prosesnya, COP bergerak setelah mendapatkan informasi untuk diolah dari UNODC. Masalahnya adalah, data yang diberikan cenderung tidak mendetail karena memang UNODC tidak memiliki wewenang untuk menelaah lebih lanjut mengenai sumber data tentang TOC di sebuah negara (Obokata 2010, 209; Chitadze 2016, 30). COP sendiri tidak memiliki mekanisme yang bisa memaksa negara untuk menyediakan data yang lebih lengkap karena akan bertabrakan dengan kedaulatan negara; sehingga kepatuhan negara anggota UNODC terhadap mekanisme yang ingin dijalankan oleh COP menjadi rendah (Caparini 2019, 12). Kekurangan dari COP ini juga bisa dilihat dari tidak responsifnya negara-negara anggota untuk terlibat langsung dengan sistem yang dibuat oleh COP. Misalnya pada tahun 2006, hanya 49\% negara anggota yang mengembalikan kuesioner dari COP untuk evaluasi (Obokata 2010, 210). Dari sisi teknis juga bisa ditemukan kekurangan yang cukup besar, yaitu ketidaksediaan database yang lengkap dari negara-negara anggota sehingga mempersulit pihak COP untuk membuat analisis mendalam mengenai kondisi TOC di negara maupun kawasan tertentu.

Selain UNODC melalui COP, salah satu institusi yang bisa bergerak dalam memberantas TOC adalah Interpol. Dibentuk pada tahun 1923, Interpol memiliki kewenangan untuk melakukan kerjasama antar kepolisian antar negara dalam menangani masalah kriminal yangmelibatkanbanyaknegara.Secaradefinisi,Interpolmelibatkan otoritas kepolisian sebuah negara sehingga seharusnya lepas dari intervensi politik. Namun, kenyataan yang terjadi adalah Interpol merupakan korban dari intervensi politik dari negara (Obokata 2010, 219). Kebingungan akan akuntabilitas juga memberikan masalah bagi kelangsungan Interpol sendiri. Rumitnya politik dan kriminalitas di negara membuat Interpol terkadang mengalami kesulitan untuk menjalankan mekanismenya; terutama jika kriminalitas semakin naik karena unsur politis.

Berkembang pesatnya Triad tidak hanya didukung dengan globalisasi seperti yang sudah dijelaskan di atas. Berkembangnya organisasi ini juga berasal dari celah yang ada baik di aturan 
hukum nasional maupun internasional. Jika aturan di dunia internasional bisa dilihat dari celah institusi internasional yang tidak mampu mengakomodasi perkembangan TOC, di tingkat nasional juga bisa ditemukan celah tersebut. Untuk di Cina daratan, tingginya angka korupsi membuat semakin suburnya aktivitas kriminal dan black economy (Lo \& Kwok 2012, 77). Fakta ini membuat Triad sebagai salah satu organisasi kriminal yang terencana, lolos beberapa kali dalam konteks hukum negara tersebut. Menjamurnya black economy tentu saja bisa menjadi ladang yang subur bagi Triad untuk menjalankan aktivitas seperti smuggling dan penjualan barang haram. Jika secara definisi, law society akan berusaha mengurangi peranan individu maupun kelompok dalam memengaruhi hukum, sehingga tidak ada individu ataupun kelompok yang berada di atas hukum itu sendiri (Lo \& Kwok 2012, 77). Kondisi tersebut tidak selalu terjadi di Cina. Ada beberapa konsep hukum yang unik dan berjalan di masyarakat, seperti rule by the people, absennya asas praduga tidak bersalah, adanya kelonggaran bagi mereka yang mengakui kesalahan, severity untuk mereka yang melawan dan mengikuti apa yang Party arahkan (Lo 2011 dalam Lo \& Kwok 2012, 77).

Kejanggalan seperti tidak ditemukannya barang bukti, korban yang tiba-tiba hilang dan dibebaskannya gembong dari Triad, menandai kondisi hukum di Cina sendiri. Sehingga, terminologi rule of law menjadi kurang tepat, justru rule by law atau rule by people cukup menggambarkan kondisi di lapangan, terutama untuk Triad sendiri.

Ketika pada tahun 1993 Bea Cukai New York menemukan upaya penyelundupan manusia yang dicurigai dilakukan oleh Triad, pada tahun 2003, US Congress Report mengungkapkan temuan bahwa the $14 \mathrm{~K}$ dan Sun Yee On terlibat dalam aktivitas perdagangan narkoba baik di domestik Amerika Serikat, maupun aktivitas ekspor ke Belanda, Filipina, Kanada, Thailand dan Afrika Selatan (Curtis dkk. 2003 dalam Lo \& Kwok 2012, 79). Tidak hanya itu, pihak Kongres juga menemukan kemungkinan keterlibatan dari Triad dalam penyelundupan manusia keluar dan masuk. Ratarata, manusia yang diselundupkan kemudian menjadi pekerja seks komersial atau ketua preman di suatu wilayah tertentu. Namun, walaupun pihak Kongres memberikan laporan adanya kemungkinan keterlibatan Triad dalam kejahatan-kejahatan, 
definisi mengenai keterlibatan Triad di dalam kegiatan kriminal yang bersifat transnasional masih ambigu. Ditambah lagi, masih banyaknya sindikat lain yang dicurigai berbeda dengan Triad sendiri. Laporan dari US National Institute of Justice justru mengeluarkan pernyataan bahwa hubungan antara Triad dengan TOC cukup lemah (Finckenauer \& Chin 2007 dalam Lo \& Kwok 2012, 79). Pernyataan tersebut justru menjadi angin segar bagi siapapun yang terlibat di dalam kejahatan tersebut; tidak adanya mekanisme kuat yang bisa menghentikannya. Di dalam negeri seperti Amerika Serikat pun masih kesulitan untuk mendefinisikan kejahatan yang dicurigai dilakukan oleh Triad ini. Ditambah dengan kurang kuatnya mekanisme milik institusi internasional seperti Interpol dan UNODC, membuat anggota Triad bisa tetap bebas beraktivitas.

\section{Simpulan}

Transnational organized crime atau lazim disingkat TOC, merupakan bentuk kegiatan kriminal yang terorganisir oleh sekelompok orang di suatu wilayah tertentu. Triad merupakan salah satu TOC yang bertahan sampai dengan sekarang walaupun memiliki bentuk yang cukup berbeda dibandingkan dengan bentuk ketika awal kemunculannya. Perubahan bentuk dari Triad sendiri merupakan dampak langsung globalisasi yang mengubah tujuan dari Triad, yang awalnya merupakan kelompok mafia menjadi kelompok yang menjalankan bisnisnya seperti korporasi. Walaupun sudah cukup banyak mekanisme, baik domestik maupun internasional, yang bertujuan untuk memberantas TOC ini, masih banyak celah yang justru menyebabkan TOC bisa bertahan. Tidak adanya definisi yang jelas dan wewenang untuk menghentikan aktivitas dari TOC dari institusi internasional, memberikan kesempatan bagi Triad untuk terus melakukan aktivitas seperti penyelundupan barang dan manusia. Walaupun secara definisi Triad merupakan sekelompok masyarakat yang awalnya merupakan resistensi dari Dinasti Qing, perlahan mulai bergeser ke arah organisasi kriminal dan memiliki basis transnasional. Kemampuan Triad untuk mempertahankan citranya di masyarakat dan secara fleksibel memanfaatkan celah hukum di Cina melalui black economy terbukti mempertahankan eksistensi Triad yang 
tetap ada mulai dari geng kecil yang beroperasi di jalanan kecil di Cina, sampai dengan mereka yang memiliki basis masyarakat besar dan terletak jauh dari dataran Cina sendiri.

\section{Referensi}

\section{Buku dan Bab dalam Buku}

Chu, Yiu Kong. 2000. The Triads as Business. New York: Routledge.

Chouvy, Pierre-Arnaud. 2013. Drug trafficking in and out of the Golden Triangle. IB Tauris.

Haryanto, Agus. 2020. "Kerjasama Internasional dalam Penanganan dan Penanggulangan Kejahatan Transnasional. (ed.) Nurul Azizah, dkk. 2020. Tindak Pidana Transnasional Terorganisasi di Asia Tenggara. Yogyakarta: Oceania Press.

Lo, Wing T. \& Kwok, Sharon I. 2012. "Traditional Organized Crime in the Modern World: How Triad Societies Respond to Socioeconomic Change" (ed.) Siegel, D. \& Bun, H. van den. 2012. Traditional Organized Crime in the Modern World, Studies of Organized Crime. New York: Springer.

Obokata, Tom. Transnational Organised Crime in International Law. Oxford \& Portland: Hart Publishing.

Post, James E., Lee E. Preston, and Sybille Sauter-Sachs. 2002. Redefining the corporation: Stakeholder management and organizational wealth. Stanford University Press.

William, Phil. 2001. "Crime, Illicit Market and Money Laundering" in Phil William \& Dimitri Vlassis (ed.) 2001. Combating Transnational Crime. London: Cass.

\section{Jurnal dan Jurnal Daring}

Bolz, Jennifer. 1995. "Chinese Organized Crime and Illegal Alien Trafficking: Humans as a Commodity”, Asian Affairs 22 (3): $147-158$ 
Campbell, Liz. 2014. "Organized Crime and National Security: A Dubious Connection?”. New Criminal Law Review: An International and Interdisciplinary Journal, 17 (2): 220251

Caparini, Marina. 2019. "UN Polices and the Challenges of Organized Crimes." Stockholm International Peace Research Institute, 1-23

Chitadze, Nika. 2016. "Global Dimensions of Organized Crime and Ways of Preventing Threats at International Level". Connections, 15 (3): 17-32

Lo, T. Wing. 2010. "BEYOND SOCIAL CAPITAL: Triad Organized Crime in Hong Kong and China", The British Journal of Criminology, 50 (5): $851-872$

Mittelman, James H. \& Robert Johnston. 1999. "The Globalization of Organized Crime, the Courtesan State, and the Corruption of Civil Society", Global Governance, 5 (1), 103-126

Pankratz, Thomas \& Hanns Matiasek. 2012. "Understanding Transnational Organised Crime. A constructivist approach towards a growing phenomenon" SIAK-Journal - Journal for Police Science and Practice 2, 41-50.

Wang, Peng \& Antonopolus, Georgios A. 2016. "Organized crime and illegal gambling: How do illegal gambling enterprises respond to the challenges posed by their illegality in China?”. Journal of Criminology, 49 (2): 258-280.

\section{Artikel Daring}

Thompson, Tony. 2003. Snakehead empress who made millions trafficking in misery" The Guardian 6 Juli 2003 [daring] https://www.theguardian.com /uk/2003/jul/o6/ immigration.china [diakses pada 14 Juli 2017

Weiss, Dena. 2014. "Organized Crime's Involvement in Sex Crimes and Human Trafficking" [daring] https://inpublicsafety. com/2014/o7/organized-crimes-involvement-in-sexcrimes-and-human-trafficking/ [diakses pada 14 Juli 2017] 
Triads and The Abilities of Transnational Organized Crime to Prevail 